\title{
Distinguished Scholar Series: Prof Tom Kochan (Sloan School of Management, Massachusetts Institute of Technology] on The Changing World of Work and Employment [and teaching note]
}

\author{
Interview by Prof Bill Roche, University College Dublin, Ireland
}

Distinguished Scholar Series

The Irish Academy of Management (IAM) launched the Distinguished International Scholar Series in 2020, under the leadership of IAM Chair, Dr Felicity Kelliher. This award honours the achievements of outstanding individuals from the international management education and research community, whose work has significantly impacted the field. Our inaugural Scholar is Professor Tom Kochan of MIT Sloan School of Management, who in conversation with Professor Bill Roche in October 2020 encapsulates the Academy's core principles of respectful debate in stimulating the exchange of ideas.

Keywords: Work, employment, distinguished scholar

(c) Sciendo

Tom Kochan, George Maverick Bunker Professor at the Sloan School of Management, is a world-renowned scholar and public intellectual. He is a faculty member in the MIT Institute for Work and Employment Research, as well as a member of the steering committee for MIT Sloan's 'Good Companies, Good Jobs Initiative'. Professor Kochan is a member of the National Academy of Human Resources, the National Academy of Arbitrators, and a past President of the International Industrial Relations Association. He was a member of President Bill Clinton's Commission on the Future of Worker-Management Relations and currently serves on the MIT Task Force on Work of the Future. His book, Shaping the Future of Work: A Handbook for Action and a New Social Contract (New York and Oxford: Routledge, 2020), provides a comprehensive public policy programme on work and employment. Professor Kochan's advocacy is grounded in empirical scholarship of breath and depth, conversant not alone with developments in the US but also in Europe and around the world. A good friend of Ireland, Tom Kochan has contributed to policy development in this country in such areas as workplace partnership and the role of education in responding the challenges posed by changes in technology. A man of personal kindness and warmth, who wears his distinction lightly, he is a role model and mentor to many scholars.

l'd like to begin by talking about Tom Kochan as a scholar and a public intellectual. Could you speak about your background and education, and in particular about figures along the way who were influential in your own academic and professional formation?

We owe an enormous gratitude to the people on whose shoulders we stand and who we try to emulate. It all started back at the University of Wisconsin, which had a long tradition of studying work employment and pioneered what they called the 'Wisconsin idea'. That is that scholarship should be certainly focused on doing good research and teaching, but also on public service and making efforts to improve things. And there was the legacy at Wisconsin 
of John R Commons, who was viewed as the father of the New Deal labour legislation. And at the national level his students helped develop the first unemployment insurance system, the first social security retirement pension system. They also developed tripartite approaches to safety and an industrial commission and workers' compensation.

Commons's students basically populated the Roosevelt administration and helped to formulate and administer the New Deal. That legacy carried forward to many years later when I was fortunate to be a student there at the Industrial Relations Research Institute. And we had people who carried that legacy like Jack Barbash and also Everett Kassalow - one of the leading international scholars whose work was based on his knowledge from the Marshall plan in Europe after World War Two. I was fortunate to work as well with Larry Cummings, my mentor in organizational behaviour and with Don Schwab, probably the best teacher of methodology - a very tough minded and rigorous scholar. And then being able to go to Cornell, where there was a whole community of scholars looking at public sector bargaining - the issue of the day - and then on to MIT. And there I was very fortunate to have my good friend, Bob McKersie, as a mentor and colleague and also Harry Katz, Michael Piore, Paul Osterman, Lisa Lynch, and now Aaron Kelly, Nate Wilmers, and Emilio Castillo - the next generation of leaders who are taking over and building a community of students all over the world that stay engaged with each other. So this is a community of scholarship and a community of activism, and I think we're privileged to be part of it.

So really right from the beginning in that tradition scholarship and public engagement were very much joined together. These people were first-rate scholars, but they also actually tried to change the world for the better?

That's right. And I'm pleased to see that those values and traditions are so deeply embedded in our profession around the world. We see people, whether it's helping NGOs and developing countries after that terrible collapse of factories in Bangladesh to build an Accord, working together with businesses and local officials. I think that's the example of the best of our field.

I think you had first-hand experience of working with John Dunlop, who wrote the first textbook in our discipline, Industrial Relations Systems, in 1958, and who served as Secretary for Labor under Gerald Ford. You worked with him on the Clinton Commission, which he chaired. You also knew his colleague and collaborator Clark Kerr, a co-author with Dunlop of another landmark study in the field, Industrialism and Industrial Man?

John was a formidable character, for sure. You knew he was in the room when he was there. He had a presence and a powerful personality and the best command of history that anyone could ever have in our field because he lived it. He studied with Keynes for a year in the 1930s. And he corrected Keynes on the relationship between inflation and real wages. And he was very proud of that. And Keynes admitted that 'Dunlop was right'. In the end, the politics surrounding the Clinton Commission didn't allow for any progress. But that was an opportunity for us to get to know each other on a personal level, a deeper level. He knew that our values were similar and we became good friends through our work on the Commission. Clark Kerr was a very different personality, very quiet, but really, again, very tough minded. Clark was the president of the University of California, like John very much involved in public policy issues. And I became a good friend of Clark Kerr, who gave me a lot of mentoring advice. When he was fired as President of the University of California by Ronald Reagan [for refusing permission to deploy the national guard on campus during the student unrest of the late 1960s] he said: 'I started and I left fired with enthusiasm'. So he had a way of coining a phrase, but he was a very respected man.

Moving to the core of your recent scholarship, I want to ask what you view as the really major current developments in work and employment in the US and beyond and the really big things that we need to understand about the changing worlds of work and employment?

The good news is these issues are on the front pages of every newspaper, just about every day in the world. Now they're on the public's mind. So we have an enormous opportunity now to influence people, to listen to them, to 
educate them about what's going on and to see if we can't make a difference. In the United States and around the world, there has been a long period of wage stagnation. Since the 1980s productivity and economic growth continued, but wages basically went flat, more in the United States and in Britain; a little bit less in Ireland, if I understand the data correctly. It's this disjuncture between economic growth, when the economy is getting better, and how average workers and their families feel left out that creates this enormous tension and disruption, anger and frustration in our societies. And the inequality that this has produced is just not sustainable. And I think just about every economist I know now agrees that the decline of unions is part of the reason for the rise in inequality. So we have to do something about restoring 'worker voice', in modern ways. So I think the two biggest things are wage stagnation and growing inequality. But along with that comes advancing technology, Al and robotics, and so many people are afraid that these technologies are going to take away their jobs or the jobs of the future.

I don't believe that. Actually I believe that we can harness modern technologies to augment work and to create new job opportunities. But we have to be very, very proactive about it. So the stagnation of wages, the growth of inequality and the challenges and opportunities around technology I think are on our front pages. Then along comes COVID and the rise of 'Black Lives Matter', and the recognition that we still have a long, long way to go to promote racial justice at work and in our societies. And these disruptions, like the Great Depression of the 1930s, are having, I think, a profound effect. They are the crisis that I hope will spur a new set of actions by the government. In the United States we have an enormous task ahead of us and with the new Administration we have probably the biggest opening of our generation. So we have to be ready with ideas that are research-based, not just political ideas, or popular ones, but well-grounded research ideas so that we can create a transformational, labour and employment policy that addresses some of these deeper problems.

In much of your work, you draw a distinction between things as they have been developing since the 1980s and what you call the 'post-war social contract at work', rooted in the New Deal Legislation of the 1930s. Can you say a little bit about the features of the 'old social contract' that's been displaced by many of the developments you have described?

I think the defining feature of that 'old social contract' was that it produced a foundational set of employment laws and institutions that allowed the economy to grow, that provided reasonable ways of resolving disputes and that allowed unions to represent more and more people. And through collective bargaining we got this tandem movement from the 1940 s to about 1980 between productivity growth and wages, so that more and more families could move into the middle-class. Now to be sure there were some people and groups left out of that: women didn't fare as well, because there was still a lot of discrimination against women in employment. Minorities still faced discrimination and were segregated into low-wage jobs. So not everybody benefited, but overall we created this rising of middle class. That defining social contract then broke down dramatically. We had the deep recession of the early years of the 1980s. We had the rise of international competition from Japan and Europe. And we had a shift in policy from a Democratic Party government to Ronald Reagan, who cracked down on labour policy - firing air traffic controllers when they went on strike, sending a signal to the private sector: "you can do that too". And all of a sudden we saw an abrupt change in wage determination. Pattern bargaining and the long-established link between wages and productivity broke down and hasn't been replaced since.

And so now we're faced with this enormous challenge of building a 'new social contract'. But obviously we can't go back to the way in which the economy worked in previous decades. We now have advancing technologies. We have globalization. We have a much more diverse workforce and we have to worry about inclusiveness. We've got new forms of work with more people in the gig economy not covered by some of our basic standards of labour legislation. So we need to create a 'new social contract' that's responsive to the time and that helps us shape the future of work, to get economic growth moving, but with wages and working conditions and productivity moving in tandem again. That I think is the absolute challenge and opportunity that we face right now.

Trade unions and the labour movement were central to the old social contract. But, as you have written, they've been struggling in trying to play a role in constructing a new social contract. From a position that is sympathetic to the labour movement you have been in some respects, quite critical of labour unions in the United States and their lack of willingness often to embrace innovation. In Shaping the Future of Work, you raise the possibility that unless unions embrace more innovation and become more effective, they could end up as a 'footnote in the history of the 20th century'. Where do you think unions and other 
groups advocating for workers' rights stand, and what role should they play in trying to develop a new social contract at work?

I am a friendly critic of the labour movement and have worked very closely with labour leaders around the country and in other countries. But I've been a constant advocate for change and innovation because I think unions really need to recognize that workers today want a direct voice. They don't want another institution telling them what they are going to do for them. They want to have a more active voice, and they want to use all these wonderful tools of social media and modern technology and artificial intelligence to communicate with each other and to find solutions to their problems. And so the challenge for labour unions today is to recognize that there's tremendous talent out there in the workforce that wants to be represented. Our survey research shows that there's an increase interest in unions. So there's a potential opportunity to reach new workers. But we need to open up our laws so that we can allow these new forms of participation and representation to flourish and for unions to adapt to those changes. Today we see all kinds of advocacy groups active in Britain and Ireland and around the world, using social media. For example, Wal-Mart, our biggest private sector employer, is vigorously and successfully opposed to any form of unionization. There is a group called 'Our Wal-Mart' and they use artificial intelligence and machine learning to provide information to Wal-Mart workers. They are not operating through collective bargaining, because they cannot form a union, or overcome Wal-Mart's resistance, but operate instead through informal community groups and social gatherings where they provide information on rights at work and advice that comes from experience of how people can deal with their problems. In the pandemic, they've been very active in helping Wal-Mart workers understand their rights to safety and in providing information on what's going on inside Wal-Mart and actually buying shares in the company and participating in the shareholders meeting - advocating that workers should have a voice and a role on the board of directors. They know that they're not going to get that, but they're agitating and trying to build community. There are many organizations like that helping employees at Starbucks, Google and Instacart and in other gig economy operators to reach the CEO with petitions highlighting what is wrong with the compensation system and the need for better scheduling. So they highlight what part-time workers, who are maybe going to school, or have families, need from their employers. Those kinds of organizations are not engaged specifically in collective bargaining, but they're finding new ways to support workers. The American labour movement needs these new organizations. They also need basic labour law changes to fix the problems that keep them from being able to organize.

And I'm encouraged that the AFL-CIO, our biggest labour federation, had a commission on the future of work and unions that issued a report last year. I spent some time working with them as did a number of other academics. And their report has to be put to work. They are creating a Technology Institute to educate local union leaders in all of these modern technologies, so that they are prepared to play a more active role. So there is progress. But I have to be frank, if we have a debate in government over the future of labour law then there needs to be a debate within the labour movement about how much they want to embrace these new approaches. And there are many people inside the labour movement and many people outside who are urging the kind of fundamental change that I'm suggesting here. So I'm hopeful that we can make progress.

One of the related areas about which you have written widely is 'workplace partnership' between employers and trade unions. What is your sense of the current state of play with workplace partnership in the United States and further afield?

I've spent a lot of time over the years working with companies and unions and studying workplace partnerships. There was the Saturn Corporation, examined with Saul Rubinstein. This innovative automobile company had partnership at every level of the organization. And then another study with collaborators examined Kaiser Permanente, a giant healthcare provider and insurance company that has probably the most comprehensive and longest lasting labour management partnership. This has been in operation now for over 20 years. Again it is quite innovative, although with its tensions and problems as well. These are good examples of what can be achieved by working together, bringing in employees and listening to their ideas, Kaiser Permanente has over 3,500 'unit-based teams', at the workplace level of doctors and technicians and service employees, continuing to work together to find ways to improve healthcare delivery and make the organization a better place to work. Then there's the case of American Water. This is small by the standards of other partnerships, but it is nationwide, with operations across the country. In a recent webinar I listened to labour and management people in this utility talk about how they are 
solving problems and how they work together in the COVID crisis; how they're working together on technology and how they're updating their benefits structures, which are very complicated and expensive. That they are working together in partnership just reinvigorates my energy to promote labour management partnerships. The next labour policy in the United States has to make this partnership strategy a core principle.

The gig economy is a major issue in contemporary work and employment. There are different views of the scale of gig platform employment, but we know that the numbers are significant and growing sharply. And we know that conditions of employment are often relatively poor and highly precarious. I wanted to ask you for your views on how the innovation and dynamism evident in this area of business can be maintained, while at the same time, addressing precarity and the seemingly Orwellian human resource management by algorithm that has become such a feature of gig economy employment.

I believe we can find sensible ways to allow these business models to move forward. And at the same time provide the basic standards that we expect for anyone who works; standards that protect their safety; protect them against discrimination and harassment; protect them if they do get hurt on the job, and provide voice. But we've got to do this in a modern way. In the US I'm a proponent of not trying to put everybody under the current national labour relations law. That won't work and will stymie gig workers' efforts and ability to exercise voice, as well as stymieing some of the innovation.

We had to extend unemployment insurance to gig workers in the pandemic with federal funds. We have about 10 or 11 million people still covered by this emergency unemployment insurance, many of whom come from that segment of the workforce. We need to find a way of covering them without viewing them as fully standard employees. I think we can do that. We can find a way of providing them with better rights, holding employers accountable for basic labour standards and still provide flexibility. So people can maybe work part-time and meet their family obligations or supplement their full-time jobs, if that's what they want. They don't all have to be full-time employees. You can still maintain agility and flexibility but with basic labour standards and, most importantly, a process for resolving disputes.

As you mentioned, the algorithms that are being used to control so many gig workers are now all set and controlled by gig employers. I think that creates more distrust and all kinds of conflicts where employees don't even know where the source of this conflict is coming from. They have a right to privacy and they have a right to information and transparency in that process and a right to resolve disputes. So we need to create new institutions. We have created arbitration systems and dispute resolution systems in our countries that fit the standard employment model. I think we can do the same for this sector, but it will take a lot of innovation and it can be very controversial on both sides. I think that will be a very big focus of the next generation of debates on labour standards and employment policy.

Another big issue is the impact that robotics and artificial intelligence are having, or are set to have, on work and employment. Enormous controversy and speculation exists in the media about the 'end of work' and surrounding supposed seismic changes accelerated by the growth of digitalization. You have a unique vantage point as a member of the MIT Task Force on the Work of the Future. Can you share an outline of the Task Force's views on the likely employment effects of robotics, artificial intelligence and related developments?

I'm privileged and pleased that we have this MIT-wide task force involving leading experts on robotics and artificial intelligence and leading labour economists and political scientists working on these issues. We think the key issue is the quality of jobs not the quantity. We need to figure out how to use technology to create a more inclusive society. We know that you have to integrate the design, development and implementation of technology with changes in work processes, including the way in which tasks are structured to make that technology payoff to its fullest potential. And we need to make sure that workers are trained ahead of time so that they can be part of the process and share the benefits and make continuous improvements. So point number one concerns the quality of jobs. Point number two is integrate technology with changes in management, workforce training and work design practices.

Point number three is that we have to rebuild the institutions governing work, with a very strong set of recommendations on rebuilding worker voice. And then there is the need to deal with people who are displaced because there will be displacement. So we need new strategies for worker adjustment and retraining and financial support for people who are out of work. But the key to all of this is to make sure that we define the problems that 
we want technology to solve. The enormous capacity of technology to solve vaccine development and distribution in the Covid pandemic is instructive. There's a lot we can learn from the potential of technology to solve problems, societal problems that can be put to good work for all of us.

Many people participating in the webinar would want me to ask you about your views on the current political situation in the US.

I think we face the biggest threat to our democracy in our lifetimes. We cannot continue to have the deep divisions and the anger and the disrespectful rhetoric that is tearing our country apart. And, and that is mirrored in some respects in other countries as well. I think if we don't address that and don't change government so our children and grandchildren see our leaders as models for what they should grow up to try to do, we are going to continue to decline as a nation. The respect that we have lost around the world will just continue. And ultimately this is going to lead to a major threat to our democracy, I don't say this lightly. I'm sorry to be so political about it, but I think that we as citizens have to speak out on behalf of what is decent and to recognize what is inappropriate about the behaviour of the current administration and do everything we can to bring us back on a path toward more shared prosperity and more civility in our society.

What do you think should be the top priorities a new administration would need to embrace in order to implement a transformative agenda around work and employment?

The first thing that we have to do is to create an aggressive programme for job creation. We've got this massive unemployment problem and unemployment is concentrated among people who are not going to be able to get those old jobs back. And they're going to be the more marginalized: more women, more minorities, more lowwage workers and a young people who haven't been able to start their careers. And so we've got to put them to work on constructive projects, like climate change and renewable energies and rebuilding our infrastructure, and to make sure that those are high quality jobs with good labour standards. Priority number two is to make sure that our transformative labour and employment policies are seen as an integral part of that economic strategy so that as we go about rebuilding and investing in the economy we make sure that we bring the workforce along with us. We need to invest in workforce skills and retraining and to rebuild worker voice so that they can inform these new technologies and have the ability to share in the benefits of the economy. We've got to extend our safety net for employment practices around areas like sick leave and parental leave, family leave and unemployment, including extending coverage to people who were excluded. Those are the priorities that need to be implemented, starting on day one of the administration and extending over the first two years, because in the American experience you have two years to get this kind of agenda to happen. Then we have congressional elections again and history suggests you lose seats in that election. After that there's a long road ahead to implement the agenda and make sustained progress. But there is a clear and strong agenda, broadly developed by many people.

You've written about the human resource management profession, sometimes as a friendly critic. In Shaping the Future of Work you say that in the US HR directors have too often been willing to act as what you call the 'perfect agents of chief executives'. And in some of your previous work, you've written about an essentially Faustian pact or bargain in which HR professionals have engaged. They have set themselves up as dynamic contributors to the development of business strategy to become 'business partners'. But in the process, you have suggested, they have forfeited the capacity independently to be critical of the actions of companies and their managements, or to adopt a more balanced perspective, in line with their professional legacy, that takes account not alone of what is in the interest of companies but also what is in the interests of workforces and indeed of the communities in which they are located. Even though, as you see it, HR directors have too often surrendered their normative legacy to win a seat on top executive teams or on boards, but yet have not succeeded in gaining the influence they sought and expected. So l'd be interested to know your sense of where the HR profession stands now and how it needs to think about its identity in the light of the call to build a new social contract at work.

I see some very talented HR executives and professionals coming out of HR programmes around the world, in the United States and in Ireland and Britain. People who are committed to a more balanced perspective. They see the 
world of work changing. They see these tensions and they see that they could have a role in helping to address them, while at the same time helping their organizations to become more productive, innovative and agile. We've got to define the role of HR as certainly supporting the strategic objectives of the enterprise, but also as having an independent professional voice that can say there are certain professional norms and standards that must be held dear, and that my peers are going to hold me accountable for, and that l'm going to bring to bear in my organization, but in a modern way.

We need to use HR analytics to understand how the world is changing and how our workforce skills could be developed in new ways. We should use online learning systems. Take IBM, for example, where they have a state-ofthe-art learning system that uses artificial intelligence tools to identify what the skills and jobs of the future look like and how to bridge from where they are today to where they need to go to keep careers moving forward. That's the kind of leadership in which the HR community should be engaged: using technology but also recognizing that they have to be an agent of the workforce, to engage workers and to support worker voice to re-establish their credibility with the workforce.

And HR needs to reach out to other stakeholders, including unions; to be effective, as professionals, at representing their businesses, but also working to build trust with their counterparts. On the labour side, we need to reinvigorate that part of our tradition, which has been lost as unions have declined. So reaching out to new voices; to the Black Lives Matter and protests that are reinvigorating the demand for voices from below, not necessarily in traditional unions. HR practitioners need to recognize that people raising their voices have to be viewed as partners in bringing about organizational change and a more inclusive set of practices in their organizations. So I think we're right on the cusp of a new transformation of the HR profession. We need to be teaching the next generation about HR analytics, but also about ethics and their broader responsibilities. If we do that and we generate both the people who go into practice and the next generation of researchers addressing these problems in the workplace, we will see a resurgence of the HR profession and research field.

As you know, there is a great deal of debate about scholarship and pressures on and trends in scholarship. It's often said that scholarship in our field is narrowing down; that career and tenure pressure is making people select more easily researchable micro-level issues, using readily available datasets, while another effect of career pressures is a lack of engagement: scholars withdrawing from engaging with the world outside the academy, other than perhaps posting things on social media or tweeting. In the light of these things, I wanted to ask what advice you would impart to early career scholars in the field?

Let me start with established academics. It's our responsibility to support young academics; to provide the opportunities to work on big problems; to obtain the resources and to help build teams, and then to work with young academics to carve out research that is rigorous and that will meet the standards of our journals. We need to support early career academics to define research problems in a big way. That's what we did in research for our book, The Transformation of American Industrial Relations. I think there were about five or six dissertations that came out of that study. And that's what we did in research on high performance work systems, a generation later, where we had about ten or eleven dissertations by people who are out there now supporting each other. They are now leaders in the field, doing great research on a variety of different topics. The work they did launched their careers because people saw that they were addressing big problems in rigorous ways, even if a small slice of a problem, while their peers were addressing another slice and another slice, and they stayed working together. They brought their work together at conferences and symposia and in all the ways in which we interact. And we build careers. And by working together with those of us who are more established providing mentorship and resources and encouragement they can be supported to move forward. So I think young people should not shy away from the big problems, but find their own niche and work together and support each other. The HR field is changing now. HR research will be very influenced by machine learning like all the social sciences. I'm enjoying watching people use innovative technologies and methodologies to advance our field, and I'm learning from them, as we all are.

I wanted to ask you where you think our academic and research field is heading? As you will know, there is a view that human resource management displaced industrial relations. And now in turn, human resource management is being displaced by organizational psychology. How can we best approach the study of work and employment? 
I think we're going to see a major paradigm shift. I think we took a first step by becoming more macro in our human resource research, bringing in sociology; bringing economics back in - not just institutional economics but modern economics. Economists now are becoming much more interested in organizational processes. We have good partnerships with economists who are beginning to see the need for institutional innovation and organizational transformation and change. We also need to use the methodological skills that we've learned from industrial and organizational psychology: rigorously collect data, test for validity and reliability and develop research designs that provide good identification of causal affects.

We have to think from a societal standpoint - acknowledging the different stakeholders in the employment relationship, to go back to Alan Fox, a revered sociologist in the British tradition who emphasized the difference between 'unitarist', 'pluralist' and 'radical' points of view. That means we have to respect the fact that it's not just the organization, the employer and management that define the problems and the orientation of our scholarship. It's a mix of interests that we have to respect, and we have to bring them into our definition of the problems that we study and the solutions that we ultimately come up with based on our empirical work. If we do that I think this field is going to continue to flourish. But if we stay separate in our bunkers: in the industrial relations tradition over here and the human resource tradition over there, then we're not fulfilling our responsibilities. And both sides will suffer as a consequence.

There is a good deal of discussion that scholars should be increasingly concerned about the 'impact' of their work. I wanted to ask how you think about impact and what kind of impacts bring you most pride in your own work as a scholar?

When I think of impact I think of the results of our work, or the ideas involved, really getting debated and put to use out there in the real world. But ideas have to be well grounded in research and not just my personal views. I certainly have my own views, but I'm hoping that if we have a comparative advantage and bring something to debates or public policies around organizational strategies or if we provide career advice for individuals, it is based on research, not just on what we may think is a good idea. And so I think of impact ultimately in terms of the effects of research and ideas on changing behaviour and changing practices. I know that academics are into Google scholar citations and journal ratings, and which ones are considered in promotion decisions. I'm fundamentally against that. Yes, we should aim for the high scholarship. But if you asked me where have I had the biggest impact, I would include some of my work in what are called 'A journals' and all of that, but where I think l've had the biggest effect is taking the next step and moving forward from those journal articles to speak to policymakers.

For example, way back in 1979, I published a paper in the Monthly Labor Review, a U.S. Labor Department journal that is read largely by people in government. It was about workers' views of unions. That was where we first found that there was this tremendous interest in joining a union. I was amazed by the amount of attention that paper got. It was in a journal that was refereed and rigorously edited. It wasn't a highly rated academic journal, but it was the right place to send that message. That paper had impact. I don't know how many citations it had, but I know it was used by labour and companies and in government. It had an influence on our recommendations later on the Clinton Commission. So put your work where it's most likely to have the most resonance and the right audience that you really want to reach, and then let the chips fall where they may.

So be open to presenting your work wherever you think there's an audience that's interested in it. A good friend from Japan said something that l'll never forget. I was getting very tired of presenting speeches based on all of the work I was involved in in the 1980s. I remarked to him: 'I've said this a hundred times, no one is going to be interested'. His response was brilliant. He said 'you may have said it a hundred times, but when you say it a thousand times, people will hear and will know'.

It remains for me to thank Tom Kochan for sharing his wisdom and expertise on the big problems that are of concern to us all and that have always animated his scholarship and his public engagement. In his poem, 'Villanelle for an Anniversary' commemorating the founding of another great Boston institution, Harvard, Seamus Heaney, composed the line: 'The books stand open and the Gates unbarred'. Tom Kochan's books will stand open for a very long time, and the gates will remain unbarred to the knowledge and wisdom that his work has imparted to all of us. 


\section{THE CHANGING WORLD OF WORK AND EMPLOYMENT}

Teaching Note

Felicity Kelliher, Waterford Institute of Technology, Ireland

The Interview conducted with Prof Tom Kochan provides a catalyst for thoughtful debate with undergraduate, postgraduate and executive management students regarding industrial relations (IR) and human resource (HR) professions. In unison with the Kochan and Dyer (2021) text, it can be used to explore multiple strategic planning, management and policy contribution opportunities including the design and implementation of a new social contract; contemplation of ethical HR management and labour support in a digitised world, and HR/IR professional stakeholder responsibilities. In addition, the interview explores the evolution of IR theory and practice, the decline of unions and worker voice and the potential for the IR/HR community of scholars to contribute to public policy development.

The insights documented in Prof Kochan's interview and in the Kochan and Dyer (2021) publication referred to within the interview present the potential to deliberate these key themes:

- The evolution of industrial relations theory and practice

- The decline of unions

- The consequences of wage stagnation

- The new social contract at work

- Restoration of worker voice in modern ways

- The gig sector/ economy

- The impact of technological advances on the future of work and employment

- Stakeholder and employment relationship responsibilities of HR professionals

- IR/HR research impact

The interview can be used in a number of formats, allowing the instructor scope to consider a variety of different angles. These formats help students to learn and develop skill sets ranging from preparation of plans and analysis of organisational and/or political environments, to conducting negotiations and live debating. A series of discussion and debate topics are provided in this teaching note, and these can be used individually or altogether depending on the focus of a facilitated session or course.

Discussion format: When using the interview to promote discussion, it is assumed that students will have read the interview prior to class discussion, and have an established understanding of the core HR/IR concepts relating to the chosen topic. Students can be asked to contemplate the discussion topic as an individual or in a group. Preclass contemplation may be requested depending on the time available for in-class discussion. The discussion topics facilitate the requirement for a decision or recommendation to be made by the student/team, which can be presented orally and/or in writing. Exploration of electronic resources to inform the recommendations are encouraged.

- Discussion topics:

- $\quad$ Transformative agenda around work and employment

- $\quad$ Restoration of worker voice

- Whether groups such as 'our Walmart' can/should inform labour policy

- Whether modern technologies influence (worker voice) (social contract) (IR) (trade union advocacy)

- Whether local union leaders should engage with modern technologies/ social media

- Whether wages and productivity should be linked

- The status of workplace partnerships

- $\quad$ The gig sector (potential) employment/ IR model

- $\quad$ Employment effects of robotics, Al and related developments

- $\quad$ Strategies to redeploy displaced workers in a digitised world

- $\quad$ The (future) stakeholder responsibilities of HR professionals

- $\quad$ Benefits and challenges in leveraging HR/IR research to inform public policy 
Considering the identified need for a new social contract in the interview and the supporting text (Kochan and Dyer, 2021), the interview can be used as a catalyst to debate the nuances of the various topics raised within the article including; the new social contract, the restoration of work voice, IR/HR social media engagement, emerging technology and the gig economy;

- Potential debate topics:

- $\quad$ Trade unions should have no role in constructing a new social contract?

- $\quad$ The decline of unions is part of the reason for the rise in inequality

- $\quad$ The community of (IR) scholars have a responsibility to help restore worker voice in modern ways and promote a new social contract

- $\quad$ Social media has no place in worker-union engagement

- $\quad$ The labour policy challenges of the gig sector are no different from other sectors.

Debate Format: This format can be used after the above discussion or as a standalone session or series of sessions, in order to offer student insight into alternative approaches to the problem or opportunity at hand. Using the debate topic that 'Trade unions should have no role in constructing a new social contract', as an example, it may be worth framing a discussion around the social contract concept and to deliberate the need for a new social contract as a first step. Instructors could then divide students into teams, and distribute a motion to be formally debated at the next session. Ideally, the debate should involve two teams of 4-5 students with one team proposing the motion and the other team opposing. Each team appoints their own chairperson and normal debating rules are applied.

Virtual learning format: The interview can also be discussed or debated in an online forum, or through the use of a collaborative whiteboard in which students develop a response to the discussion topic or debate motion through rapid content development. A defined time period can be set to enhance the real-life collaborative experience, where decisions are made in real-time and electronic sign off of the final recommendation is required by all team members.

\section{Supporting text:}

Kochan, T.A. and Dyer, L. (2021). Shaping the Future of Work - A Handbook for Building a New Social Contract. Routledge, Taylor and Francis Group, NY and London. 